IZA DP No. 5169

Poorer Health - Shorter Hours?

Health and Flexibility of Hours of Work

Johannes Geyer

Michal Myck

September 2010 


\title{
Poorer Health - Shorter Hours? Health and Flexibility of Hours of Work
}

\author{
Johannes Geyer \\ DIW Berlin
}

\author{
Michal Myck
}

CenEA, IFS and IZA

\section{Discussion Paper No. 5169 \\ September 2010}

\author{
IZA \\ P.O. Box 7240 \\ 53072 Bonn \\ Germany \\ Phone: +49-228-3894-0 \\ Fax: +49-228-3894-180 \\ E-mail: iza@iza.org
}

Any opinions expressed here are those of the author(s) and not those of IZA. Research published in this series may include views on policy, but the institute itself takes no institutional policy positions.

The Institute for the Study of Labor (IZA) in Bonn is a local and virtual international research center and a place of communication between science, politics and business. IZA is an independent nonprofit organization supported by Deutsche Post Foundation. The center is associated with the University of Bonn and offers a stimulating research environment through its international network, workshops and conferences, data service, project support, research visits and doctoral program. IZA engages in (i) original and internationally competitive research in all fields of labor economics, (ii) development of policy concepts, and (iii) dissemination of research results and concepts to the interested public.

IZA Discussion Papers often represent preliminary work and are circulated to encourage discussion. Citation of such a paper should account for its provisional character. A revised version may be available directly from the author. 
IZA Discussion Paper No. 5169

September 2010

\section{ABSTRACT \\ Poorer Health - Shorter Hours? Health and Flexibility of Hours of Work ${ }^{*}$}

We analyse the role of health in determining the difference between desired and actual hours of work in a sample of German men using the Socio-Economic Panel Data for years 19962007. The effects of both self-assessed health and legal disability status are examined. About $60 \%$ of employees report working more than they would wish with the mean difference of -3.9 hours/week. We estimate static and dynamic model specifications allowing for autoregressive nature of the dependent variable and testing for the role of lagged health status. Important differences are found between east and west German Länder. In the west we find statistically significant role of general health measures in determining the disequilibrium. Employees in bad health want to work on average by about 0.4 hour/week less according to the static specification, and by about 1 hour/week less if dynamics of health and of the disequilibrium are taken into account. This is respectively $10 \%$ and $25 \%$ of the mean difference. We find no effects of legal disability status on the disequilibrium which we interpret as a reflection of stronger legal position of disabled employees. In both east and west we find significant state dependence in the hours disequilibrium.

JEL Classification: J21, J14

Keywords: hours worked, health, disability, labour market flexibility

Corresponding author:

Michal Myck

Centre for Economic Analysis, CenEA

ul. Królowej Korony Polskiej 25,

Szczecin

Poland

E-mail: mmyck@cenea.org.pl

\footnotetext{
* The authors thank Viktor Steiner and Peter Haan for very helpful comments. We would also like to thank Pawe Śmietanka for his very helpful assistance in the early stages of work on this paper. Financial support from the German Science Foundation (DFG) through project "Economic risks, savings of the elderly, and the impact of public policy - an empirical analysis for Germany" (STE 681/81 ) is gratefully acknowledged. The usual disclaimer applies.
} 


\section{Introduction}

Deteriorating health may result in a direct welfare loss and in an indirect lowering of the quality of life through limitations on labour market activity and, as a further consequence of that, the level of income. The degree to which poor health indirectly affects welfare will primarily depend on how easy it is to maintain employment and/or income once health worsens. It is well documented in the literature that poorer health is correlated with lower labour market participation and may lead to loss of employment (e.g., Bound et al., 1999; Riphahn, 1999; Blundell et al., 2002; Pelkowski and Berger, 2004; Kalwij and Vermeulen, 2008). However, health has also an affect on economic outcomes of those individuals who remain active on the labour market. Poor health might reduce productivity and thereby wages and also affect the number of hours individuals work (e.g., Cai et al., 2008; Jaeckle and Himmler, 2010). ${ }^{1}$

The income effect of a lower wage rate of individuals in bad health could be compensated by longer working hours but poor health might also increase the disutility of labour. Therefore, the direction of this effect is a priori indeterminate. Moreover, theoretical arguments and empirical evidence suggest that individuals may not be able to freely adjust their working hours to the desired level which again contributes to the welfare cost of poor health. ${ }^{2}$ Many studies report a significant degree of dissatisfaction with the current intensity of work. Studies using US and Canadian data show that usually about $30 \%$ of men would prefer to work longer hours, while about $10 \%$ would prefer shorter hours relative to what they currently work (e.g., Altonji and Paxson, 1988; Dickens and Lundberg, 1993; Kahn and Lang, 1991), suggesting an important degree of constraints on the labour market with regard to the free choice of hours of work. In Europe, on the other hand, working men often state preference for a reduction in hours of work. For example, Boeheim and Taylor (2004a) and Stewart and Swaffield (1997) show for the UK that about 30\% of all men would like to reduce their working hours while 10\% would like to work more. Euwals et al. (1998) report similar findings for the Netherlands.

Overall, many studies suggest that even in countries with liberal labour market institutions disequilibria between preferred and desired hours prevail, and that adjustment to desired hours of work may be costly. For example Altonji and Paxson $(1986,1988)$ and Martinez-Granado (2005) show for the US that changes in working hours occur more often

\footnotetext{
${ }^{1}$ For a review of earlier studies, see Currie and Madrian (1999).

${ }^{2}$ Kahn and Lang $(1995,1992)$ summarise theoretical models that imply hours constraints and test them empirically with US data.
} 
between than within jobs. Blundell et al. (2008) find the same pattern for the UK. From the policy point of view it seems important to examine whether the disequilibria differ by health status, an issue which has so far remained unexamined. This is in particular relevant given the growing concerns about the relationship between health policies and labour market participation and measures related to extending working lives.

In this paper we focus on the relationship between health and hours of work in Germany in the years 1996-2007 using data from the German Socio-Economic Panel Study (SOEP). While there are many studies showing that health is an essential determinant of employment, the focus here is on its effect on the desired and actual intensity of work. The relatively inflexible nature of the German labour market, and the persisting differences in labour arrangements between east and west make the issue of hours adjustment particularly interesting (e.g. Wolf, 2000).

The empirical analysis of the effect of health on labour market outcomes entails several important identification issues, which are related to the complex nature of their relationship including employment, wages and hours of work. Health may affect the probability of employment, work intensity and productivity. At the same time, however, it may be affected by the intensity of work and the level of income. Moreover, in the model of Grossman (1972) poorer health on the one hand results in reduced total labour input, but the relationship may be additionally stronger by the endogeneity of health if individuals treat it as investment in human capital (Lee, 1982; Jaeckle and Himmler, 2010). There is also growing literature on the consequences of non-employment on health (e.g., Clark and Oswald, 1994; Bockerman and Ilmakunnas, 2009; Haan and Myck, 2009).

With the data at hand it is in our view impossible, however, to estimate a model that would at the same time account for the endogeneity of employment status, hours of work and wages with respect to health and combine this with the analysis of hours disequilibrium analysis. We therefore analyse the relationship between hours and health from a different angle, and focus on the identification of determinants of individual labour market disequilibrium on the intensive margin. Importantly, given the nature of health and the hours disequilibrium, we are able to account for the dynamics in the processes which are found to play a significant role. Our study focuses on an unbalanced panel of German male employees aged 20-59, and the SOEP data provide a rich set of variables allowing detailed analyses of the aspects we examine. The longitudinal aspect of the SOEP and the consistency of questions being asked in the survey allows us to use both static and dynamic panel methods, with the latter allowing to uncover important time effects of hours adjustment and effects of lagged 
health status. The SOEP contains also different types of health measures, two of which - a self-assessed general health measure (SAH) and the legal disability status and degree (LDS) - are used in the analysis.

The results confirm very limited part time work practices among men in Germany and the data show substantial differences between actual and desired hours of work, with the mean difference of about -3.9 hours per week. This difference is about 1 hours per week higher in the east than in the west. Interestingly men in the west work slightly shorter hours (about 2 hours less per week). We find consistent evidence that health is an important determinant of the hours disequilibrium in the west but no such evidence for east German data. In both regions, however we confirm the role of the persistence of the disequilibrium and thus a confirmation of the importance of a dynamic approach to modelling the difference between actual and desired hours. Once the dynamics are accounted for, self-assessed poor health explains about $25 \%$ of the mean difference between actual and desired hours. Interestingly we find no significant effects of the legal disability status on the disequilibrium, which may be interpreted as a result of a set of legal labour market advantages granted to disabled individuals.

We start the paper by discussing the approach we take to modelling of the observed disequilibrium between desired and actual hours of work in Section 1. This is followed by data description in Section 2 and presentation of results in Section 3. Conclusions complete the paper.

\section{1 "Individual disequilibrium" in hours of work}

The focus of our analysis is the impact of health on the observed discrepancy between realised and desired hours of work to which we refer to as the "individual hours disequilibrium". 3 Studies of determinants of labour market intensity usually assume a high degree of flexibility in the choice of hours of work, although it has been recognised for a long time that simple hours choice models cannot generate the observed highly concentrated hours distribution (Kahn and Lang, 1991; Dickens and Lundberg, 1993). So far the literature has ignored the role played by health in determining such disequilibria and we aim to fill this gap. The disequilibrium may have particular relevance for Germany given the relatively inflexible character of its labour market. In the simplest framework of full flexibility on the labour

\footnotetext{
${ }^{3}$ This difference, what we call "individual hours disequilibrium", is sometimes referred to as "hour tension" (see e.g., Merz, 2002). Or, as Boeheim and Taylor (2004b) put it, employees can be considered "over-" or "underemployed".
} 
market one would expect that if health has an effect on wages and/or desired hours of work, individuals would freely choose their preferred intensity conditional on their wage, and so health would not present any additional constraint. However, if the intensity of work cannot be adjusted freely to suit one's preferences, an important question to ask is of the role of health in determining this disequilibrium.

The dependent variable we analyse is the difference between desired and actual hours of work, where the desired hours are answers to the following question in the SOEP survey:

- If you could choose your own number of working hours, taking into account that your income would change according to the number of hours: How many hours would you want to work?

Since the question specifically takes into account the change in income resulting from different work intensity, one can assume that it implies the preferred individual point on the budget constraint, unrestricted by demand conditions. Thus if labour market demand were perfectly flexible, we would expect there to be no systematic differences in this measure of individual disequilibrium. This is largely the case in the data, but as we shall see there are several factors, including health, which significantly affect this disequilibrium. Figure 1 shows kernel densities of key variables used in the analysis: actual hours of work, desired hours of work and the difference between them, i.e. the distribution of the "individual disequilibrium" variable. The densities are based on pooled SOEP data for men aged 20-59 for years 1996-2007 and are given separately for individuals living in east and west German Länder.

Figure 1: Kernel densities of weekly hours by region

$1 \mathrm{~A}$ - Actual hours of work

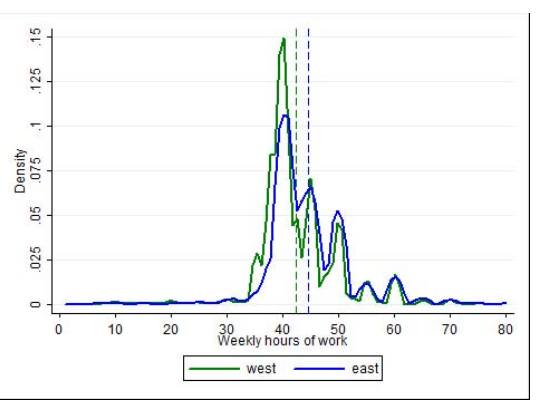

1B - Desired hours of work

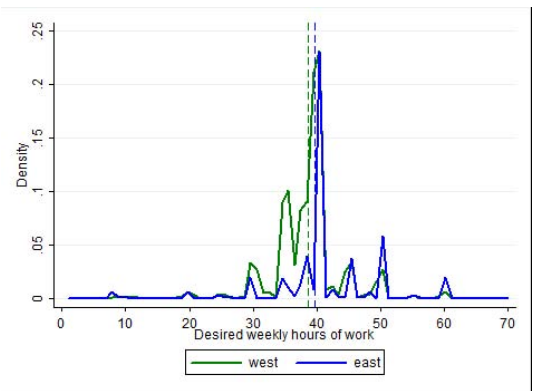

$1 \mathrm{C}$ - Individual disequilibrium

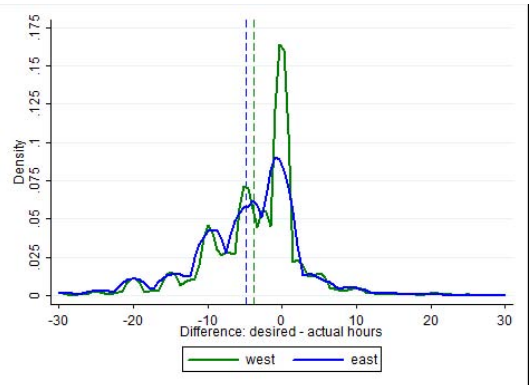

Source: Authors' calculations based on SOEP 1996-2007 data.

Figure 1A shows the distribution of actual hours of work. This distribution has the characteristic kink at around 40 working hours. Part-time work is very uncommon among men in Germany and the distribution piles up at points above 40. Mean working hours are slightly higher in east Germany. Figure 1B shows the corresponding distribution of desired 
hours. This distribution has much less mass above 40 hours and interestingly there is also a spike at 30 hours which has no corresponding shape in the actual distribution. Looking at the difference of these two distributions, we see that in figure $1 \mathrm{C}$ the mean difference is negative. On average men would want to reduce working time by about four hours. Nearly $30 \%$ do not want to change their working time and about $60 \%$ want to reduce it. Conditional on the desire to reduce working time, the average is 7.9 hours per week. The unconditional difference is slightly higher in east Germany and for men in poor health.

\subsection{Modelling determinants of the individual hours disequilibrium}

The individual hours disequilibrium is thus defined as: $\kappa_{i t}=h_{i t}^{*}-h_{i t}$, where $h_{i t}^{*}$ are the desired hours, and $h_{i t}$ are the actual hours of work. Formally we could present this difference, as a difference between unconstrained hours of work, resulting from individual optimisation conditional on individual gross wage, $w_{i}$, the tax and benefit function, $\chi$, and taste-shifting characteristics, $X_{i}$ :

$$
h_{i t}^{*}=f\left(U_{i t}^{\max } \mid w_{i t}, \chi_{t}, X_{i t}\right)
$$

and the observed actual hours are a result of the constrained choice including demand restrictions $\left(D_{i t}\right)$ :

$$
h_{i t}=g\left(U_{i t}^{\max } \mid w_{i t}, \chi_{t}, X_{i t}, D_{i t}\right)
$$

The individual disequilibrium would thus depend on a set of taste-shifting variables on the one hand, and on demand factors such as time of the interview, occupation and tenure on the other. Interestingly health might affect both demand for and supply of labour, conditional on the wage level. Less healthy individuals may wish to work shorter hours due to health constraints, or longer hours due to income effects of reduced earnings capacity. At the same time, if employers for some reason cannot freely adjust wages, they may require unhealthy individuals to work longer hours. Different nature of poor health may also have different effects on the disequilibrium. The legal advantages of the official disability status may imply that those with disability may be less constrained by required overtime, but at the same time might find it more difficult to justify working overtime to their employers.

Our basic specification of the estimated equation is:

$$
\kappa_{i t}=\gamma H_{i t}+\beta X_{i t}+\nu_{i}+\varepsilon_{i t}
$$

where $H_{i t}$ are variables controlling for health, $X_{i t}$ are other observable characteristics including individual characteristics and demand-related variables, $\nu_{i}$ is an individual fixed 
effect, and $\varepsilon_{i t}$ is time-varying residual. Since $\kappa_{i t}$ is a combination of preferences and demand constraints, it is likely that there is a dynamic component in the process. One could thus represent equation (3) in a dynamic form as:

$$
\kappa_{i t}=\sum_{s=1}^{S} \delta_{s} \kappa_{i, t-s}+\sum_{r=0}^{R} \gamma_{r} H_{i t-r}+\beta X_{i t}+\nu_{i}+\varepsilon_{i t}
$$

The characteristics of the process are largely an empirical question, but they seem important from the point of view of the estimation of the effects of shocks to the equilibrium, resulting for example from changes in health status. As we shall see the estimated consequences of shocks to health on the individual disequilibrium significantly depend on whether this dynamic element is taken into account. This is particularly important given the high degree of persistence in the health process in the German data (Haan and Myck, 2009).

The role of the determinants of the individual disequilibrium are estimated using three main specifications. We take advantage of the panel dimension of the data to estimate, on the one hand, the relationship in its static representation (equation 3) using the random and fixed effects models, and on the other, the dynamic formulation presented in equation (4). In the latter case we use the system GMM estimator suggested by Arellano and Bover (1995).

\section{$2 \quad$ Data and descriptive statistics}

Our analysis is based on data from the German Socio-Economic Panel Study (SOEP) for the years 1996-2007, with the first and last years of the series used only for generating lags and selection controls for the principal 1997-2006 sample. The SOEP data contains detailed information on a large number of German households, including details of the number of hours worked (contractual, actual, and desired) and several health indicators. ${ }^{4}$ Our analysis focuses on a sample of prime age men (20-59) in east and west Germany. Women, civil servants and self-employed individuals are excluded from the sample.

\subsection{Health status}

We choose two different health measures from SOEP that are available for the whole observation period. First of all, we use a 5 -scale measure of self-assessed health (SAH). ${ }^{5}$ Secondly, we control for the legal disability status and the degree of disability. While the latter is more

\footnotetext{
${ }^{4}$ See, e.g., Wagner et al. (2007) for more information on SOEP.

${ }^{5}$ The specific question is "How would you describe your current health?" and respondents can choose between "very good", "good", "satisfactory", "not so good", and "bad".
} 
directly linked to health-related capability of labour market involvement, ${ }^{6}$ the first measure is much broader and covers both physical and mental health. Several studies have pointed out that the self assessed status may contain measurement errors, the extent of which may be related to individuals' labour market status, and that it may only imperfectly reflect the "true" state of health (e.g., Bound, 1991; Bound et al., 1999). However, the SAH measures strongly correlate with "objective" health (e.g., Wannamethe and Shaper, 1991; Idler and Benyamini, 1997; Larsson et al., 2002), and it has been shown that at least within nation and gender groups the SAH should provide consistent reflections of health status (Lindeboom and van Doorslaer, 2004). In the particular application in this paper we limit the analysis to prime-age working men, which is a relatively homogenous group, and thus reporting heterogeneity ought not to be a major problem. In the analysis the variable is dichotomised into "good" which includes the top two SAH categories and "poor" defined by the bottom three.

The disability indicator comprises two different types of disability that are not differentiated in the survey, namely legal severe disability status and reduced earnings capacity (REC) which may qualify for full or partial disability pensions. The degree of legal severe disability is measured in percent in the range between 20 and 100. In general, "severe disability" status applies to individuals with a disability degree of $50 \%$ or more. It implies several protective rights with respect to the labour market without imposing any maximum working hours. ${ }^{7}$ Moreover, employers with more than 19 employees are obliged to employ at least $5 \%$ severely disabled or face a certain monthly contribution. This requirement might imply greater bargaining power of the severely disabled employees vis-a-vis employers with respect to the choice of hours, which is confirmed in our analysis.

In contrast, the regulations on REC cover individuals not capable of working in a "normal" employment relationship which prior to 2001 was expressed in terms of earnings as inability to earn a wage of more than $1 / 7$ of the average monthly wage over a longer period of time. Since 2001 it refers to the number of hours worked, with inability to work more than 3 hours per day making individuals eligible for full REC (6 hours for partial REC). Reduced earnings capacity also implies eligibility for disability pensions. While in the data we cannot distinguish legal and REC disability status, given the incentives the REC provides we are unlikely to observe many individuals with REC active on the labour market.

\footnotetext{
${ }^{6}$ The survey question reads "Are you legally classified as handicapped or capable of gainful employment only to a reduced extent due to medical reasons?." and "What is the extent of this capability reduction or handicap according to the most recent diagnosis?" (in \%).

${ }^{7}$ Individuals with severe disability status acquire special dismissal protection, longer annual leave, favourable tax treatment and an early retirement option.
} 
Generally therefore, we expect the majority of employed respondents who answer to have a health related handicap to have the legal severe disability status.

Table 1 shows descriptive statistics of health status in west and east Germany. SAH is reported as dichotomised into a "poor health" variable, where poor health is classified as reported "bad", "not so good" and "satisfactory". This type of dichotomisation leads to high proportions of individuals classified as being in "poor health" both out and in work, and is dictated by the fact that our analysis focuses on the employed sample in which the proportion of those in "bad" and "not so good" health among prime-age men is very low. According to the chosen dichotomisation about $40 \%$ of employees in the west declare "poor health" and this proportion is a few percentage points higher in the east. Disability on the other hand is declared by a lower proportion of western employees compared to the working population in the east. Regional differences are higher for non-employed men, though the small sample size in this case leads to high variation in the computed statistics for both east and west over time. As many as $56 \%$ of non-employed men in the east declare "poor health" in 2002 , and this proportion is even higher at $63 \%$ for non-employed males in the west. Interestingly both "poor health" and disability show a growing trend among the non-employed, but are relatively stable among the sample of employees.

\subsection{Potential sources of sample selection bias}

As in all studies related to labour market participation our results must be carefully analysed with regard to several potential sources of sample selection bias. The analysis is focused on men aged 20-59 and excludes individuals who at any time in the survey are civil servants or self-employed (and in the relevant age range). We also exclude students, though only at the time of their study, i.e. once individuals leave education they are included in the sample. Naturally, the data on actual and desired hours of work comes only from employed individuals. About $4.9 \%$ of all men in the chosen age group are never observed as working during the time of their participation in the survey. A larger proportion of some $40 \%$, however, are non-employed at some point in time covered by the data. In these cases we distinguish between absorbing and non-absorbing selection, and we allocate individuals to the first category if during the time in which they participate in the survey they are observed as non-employed in at least two last years covered by the data. All other forms of nonemployment are treated as non-absorbing selection. The distinction in our view is justified by the focus of the paper, since health may be an important reason for permanently leaving the labour market and we want to distinguish permanent departures from non-permanent 
ones. As Haan and Myck (2009) have shown, deteriorating health among German men significantly affects the probability of being employed, and given the high degree of state dependence in health, non-employment resulting from deteriorating health may be long-term or permanent. In all specifications we therefore test for both absorbing and non-absorbing selection bias following the method proposed by Verbeek and Nijman (1992). While this has been developed in the context of the random effects model, it is also applicable to fixed effects models (Wooldridge, 2004), and we include absorbing and non-absorbing selection controls also in the dynamic panel models. In the relationships we estimate including selection controls in the models has negligible effect on the estimated coefficients in all specifications in particular if fixed effects are accounted for.

Due to the nature of the dynamic GMM estimation the sample used for our main analysis is restricted further, and includes only the individuals who have a series of at least four uninterrupted observations of the actual and desired hours of work. In addition we need to drop the initial observations for which there are no lagged instruments. This reduces the sample and limits it to individuals with strong labour market attachment. Table 2 shows the degree of this reduction. The number of observations in the RE/FE sample is 21196 and 6571 in the west and east respectively, while for the GMM sample it is 11930 and 3530. Even if we exclude years 1997 and 1998 from the static estimation samples the GMM samples are about $65 \%$ of the size of $\mathrm{FE} / \mathrm{RE}$ samples. As we show in Section 3 this further selection does not remain without consequences on the static estimation in particular in the east. The results using west German data are however generally stable across the samples. Since the dynamic estimations show important features of both the German labour market and the relationship between health and the individual disequilibrium in hours, we take these as our principal specification.

Basic descriptive statistics on the static (FE/RE) the dynamic (GMM) samples and are given in Table 3. German men work about 43 hours per week and on average express the desire to work approximately 4 hours less. Work time is higher in the east than in the west and employees in the east on average want to reduce their work intensity by about an hour more then those in the west. Among employees health seems to be slightly better in the west than in the east, but at the same time east German employees are less likely to have the legal disability status. This discrepancy may relate to disability-related employment selection. The table shows that as far as observable characteristics are concerned there is little evidence of important differences between the employee samples for static and dynamic estimations. Selection control variables, however show that the GMM sample is much more 
stable with much lower proportions of individuals with non-absorbing and absorbing selection indicators. As one could expect both types of selection indicators are also higher for the east than for the west samples.

\section{Results}

Results of the GMM estimations are presented in Tables 4 and 5 for west and east Länder, while Tables 6, 7 and 8 show results of static random (RE) and fixed (FE) effects estimations run using different selection criteria to demonstrate the effect of restricting the sample to facilitate the dynamic GMM and to show the effects of controlling for selection in the static specifications. Results of both static and dynamic estimations significantly differ by region and we discuss them separately.

For the GMM specifications we present estimates of four equations two using the difference GMM estimator (Arellano and Bond, 1991) and two using the system GMM estimator (Arellano and Bover, 1995). In the case of each of these we estimate the models with and without selection controls for absorbing and non-absorbing selection. In the GMM results selection controls are not statistically significant and including them in the estimations has negligible effect on the values of the estimated coefficients. Since in the case of the dynamic panel only those observed as not working after a relatively long spell of employment are seen as "selecting out" of work, this could be a result of the specificity of the sample. For this reason we show static FE and RE estimations run on the full sample in each case again with and without selection controls (Table 6). In this case, while several selection controls appear significant, the effect of including them on the coefficients of interest, i.e. those on health is noticeable only in the case of RE specifications. Once fixed effects are controlled for selection out of the sample appears to have little effect on the estimations of the relationship between health and the hours disequilibrium.

The GMM system estimates for both east and west suggest statistically significant persistence in the difference between desired and actual hours. The estimated coefficients are small (approximately 0.1 in the east and 0.2 in the west) but they suggest that not only is there likely to be persistence in the discrepancy between desired and actual hours, but also that there may be positive feedback from past disequilibria, contributing to growing dissatisfaction with current hours. According to the estimates on west German employees a five-hour disequilibrium in year t-2 would translate to almost six and a half hours at time t.

The results show interesting effects of health on the disequilibrium, with the coefficients 
on SAH "poor health" being stable and significant across specifications using the west German data. The system GMM estimation suggests a negative effect of poor health of about 0.4 hours on the hours disequilibrium, with less healthy individuals desiring to reduce their work intensity. Importantly, we also find significant effects of lagged poor health status. These effects combined would suggest that a permanent health shock at time t- 1 would lead an individual on average to desire from three-quarters to one hour less than his actual hours of work. This is about a quarter of the mean difference between desired and actual hours in the data. Interestingly, no such effects are found in the east, where while the hours disequilibrium also seems to have a dynamic element, the effects of SAH poor health are actually positive, though they are not significant in the GMM difference estimation.

Official disability status does not have any significant effect on the hours disequilibrium either in the east or west of Germany, which may initially seem surprising. As we noted earlier, however, official disability grants employees certain specific legal advantages which may give them a greater bargaining power vis-a-vis their employers, and thus facilitate easier adjustment to desired hours of work. Another possible explanation may be that working disabled individuals have easier access to "outside options" and those observed as working may be a more selected sample of those disabled who are satisfied with their work conditions including its intensity.

Tables 7 and 8 show some further robustness checks concerning the role of sample selection in our analysis. This time, the selection relates to moving from the samples for panel estimation (as reported in Table 6) to the GMM sample. Tables 7 and 8 report four sets of random and fixed effect estimations using three different samples:

- RE/FE-1: static samples without lagged health status (the same as in Table 6)

- RE/FE-2 static samples with lagged health status

- GMM sample used for estimations with and without lagged health status

Once again the estimations are run separately for west (Table 7) and east (Table 8) Germany, and they all include selection controls. The results, in particular for the east, suggest important consequences for the estimation of moving from the full RE/FE sample to the restricted GMM sample. Estimation using west German data is far more stable and shows less variation due to sample composition. For example, although east German data in all specifications confirms a positive effect of "poor health" on the hours disequilibrium, the results are only statistically significant both in the RE and FE specifications when based on the 
restricted GMM sample. Other specifications give non-significant coefficients of much lower magnitude. On the other hand, all random and fixed effects estimations run on the west German sample produce results similar in magnitude to those estimated using the GMM, and the effect of the GMM sample restriction is much lower.

\section{Conclusion}

How health relates to labour market activity is a key issue for employment policies and an important aspect in understanding individual economic behaviour. While it is relatively well established that health plays an important role in determining employment, its effect on productivity as well as on choices and opportunities on the 'intensive margin' of employment are not yet very well researched. We believe that if labour market policy aimed at increasing employment is to be effective, in particular concerning participation of older individuals, then more attention ought to be given to the constraints imposed by poor health on both those still employed and those seeking employment. This paper focuses on the former group and the quantitative results may have important policy implications.

Using data on prime-age men from the German Socio-Economic Panel for years 19962007 we examined the effect of health on the hours of work disequilibrium, defined as the difference between desired and actual hours of work. The analysis has been set in a dynamic framework to capture state dependence of the disequilibrium and lagged effects of health on welfare at work. Focusing on the sample of employees and limiting it further to allow for the dynamic estimation entailed important sample restrictions, but using various selection controls, following Verbeek and Nijman (1992) and Wooldridge (2004), we showed that selection into employment has negligible effect on the estimation of key coefficients. Moreover, for the west German sample the further sample restrictions to allow the application of the dynamic GMM estimator of Arellano and Bover (1995) produces very similar results to those obtained on the non-restricted sample.

Most important results of the study include our identification of state-dependence in the hours disequilibrium suggesting positive effects of lagged values on current difference between desired and actual hours of work. The magnitude of this effect is about 0.2 and 0.1 for the first and second lags accordingly in the west and is lower but also statistically significant in the east.

Concerning the key parameter of our interest, namely health, we found that self-assessed current and lagged "poor health" has significant effects on the hours disequilibrium in the 
west, with unhealthy individuals expressing the desire to work shorter hours relative to their actual hours of work. Current "poor health" implies an increase of the disequilibrium by about 0.4 hours, while lagged "poor health" about 0.3 hours. Depending on the estimation including state dependence the effect of long-term "poor health" is on average between 0.8-1.0 hour. This is about a quarter of the mean hours disequilibrium observed in the data. Results for the east German sample proved less stable and more sensitive to sample restrictions. The dynamic GMM estimation in this case found a surprising positive effect of "poor health" on the difference between desired and actual hours of work. While this could be a reflection of a possible income effect of poor health on intensity of work, the more likely explanation seems to be related to the sample restrictions imposed by the method we used. Unlike for the sample using data from western German Länder, the static results based on unrestricted east German data showed no significant effects of health on the hours disequilibrium.

One surprising result of the analysis relates to the lack of any effect of disability status on the hours disequilibrium. This could be interpreted as the effect of a stronger position of legally disabled individuals on the labour market, in which case the one could argue that the stronger bargaining position allows disabled individuals to chose their hours of work more freely. On the other hand this might be a reflection of a particular sample selection, with the working disabled individuals being more likely to leave employment in case of their dissatisfaction with their working conditions. One way or the other the lack of the effect of disability status on the hours disequilibrium and the contrast to the effect of general "poor health" points towards potentially interesting questions concerning the role of legislation for hours adjustment on the labour market.

It seems intuitive that the possibility of flexible hours adjustment, in particular among older and less healthy individuals would play a role in their decisions to remain active on the labour market. Health has been shown to be a significant factor in determining employment, and we have demonstrated that its deterioration may contribute to the increase in the dissatisfaction with the intensity of work. This suggests that there is potential to improve work quality by making working time more flexible to those whose health deteriorates, and who do not qualify for disability. Improved opportunities for hours adjustment might be an important element contributing to the extension of active involvement on the labour market and greater flexibility might encourage those who already left it to return to active participation. 


\section{References}

Altonji, J. G. and Paxson, C. (1986). Job characteristics and hours of work. In Ehrenberg, R. G., editor, Research in Labor Economics, volume 8, pages 1-55. Westview Press, Greenwich.

Altonji, J. G. and Paxson, C. H. (1988). Labor supply preferences, hours constraints, and Hours-Wage trade-offs. Journal of Labor Economics, 6(2):254-276.

Arellano, M. and Bond, S. (1991). Some tests of specification for panel data: Monte carlo evidence and an application to employment equations. Review of Economic Studies, $58(2): 277-297$.

Arellano, M. and Bover, O. (1995). Another look at the instrumental variable estimation of error-components models. Journal of Econometrics, 68:29-51.

Boeheim, R. and Taylor, M. P. (2004a). Actual and preferred working hours. British Journal of Industrial Relations, 42(1):149-166.

Boeheim, R. and Taylor, M. P. (2004b). And in the evening she's a singer with the band second jobs, plight or pleasure. Discussion Paper No. 1081, IZA, Bonn.

Blundell, R., Brewer, M., and Francesconi, M. (2008). Job changes and hours changes: Understanding the path of labor supply adjustment. Journal of Labor Economics, 26(3):421453.

Blundell, R., Meghir, C., and Smith, S. (2002). Pension incentives and the pattern of early retirement. Economic Journal, 112(478):C153-C170.

Bockerman, P. and Ilmakunnas, P. (2009). Unemployment and self-assessed health: Evidence from panel data. Health Economics, 18(2):161-179.

Bound, J. (1991). Self-reported versus objective measures of health in retirement models. Journal of Human Resources, 26(1):106-138.

Bound, J., Schoenbaum, M., Stinebrickner, Todd, R., and Waidmann, T. (1999). The dynamic effects of health on the labor force transitions of older workers. Labour Economics, 6(2):179-202. 
Cai, L., Mavromaras, K. G., and Oguzoglu, U. (2008). The effects of health and health shocks on hours worked. IZA Discussion Papers 3496, Institute for the Study of Labor (IZA).

Clark, A. E. and Oswald, A. J. (1994). Unhappiness and unemployment. Economic Journal, 104(424):648-659.

Currie, J. and Madrian, B. C. (1999). Health, health insurance and the labor market. In Ashenfelter, O. and Card, D., editors, Handbook of Labor Economics, volume 3 of Handbook of Labor Economics, chapter 50, pages 3309-3416. Elsevier.

Dickens, W. T. and Lundberg, S. J. (1993). Hours restrictions and labour supply. International Economic Review, 34(1):169-192.

Euwals, R., Melenberg, B., and van Soest, A. (1998). Testing the predictive value of subjective labour supply data. Journal of Applied Econometrics, 13(5):567-585.

Grossman, M. (1972). On the concept of health capital and the demand for health. Journal of Political Economy, 80(2):223-55.

Haan, P. and Myck, M. (2009). Dynamics of health and labour market risks. Journal of Health Economics, 28:1116-1125.

Idler, E. L. and Benyamini, Y. (1997). Self-rated health and mortality: A review of twentyseven community studies. Journal of Health and Social Behavior, 38(1):21-37.

Jaeckle, R. and Himmler, O. (2010). Panel data estimates considering selection and endogeneity. Journal of Human Resources, 45(2):364-406.

Kahn, S. and Lang, K. (1991). The effect of hours constraints on labour supply estimates. The Review of Economics and Statistics, 73(4):605-611.

Kahn, S. and Lang, K. (1992). Constraints on the choice of work hours: Agency versus Specific-Capital. Journal of Human Resources, 27(4):661-678.

Kahn, S. B. and Lang, K. (1995). The causes of hours constraints: Evidence from canada. The Canadian Journal of Economics / Revue canadienne d'Economique, 28(4a):914-928. ArticleType: research-article / Full publication date: Nov., 1995 / Copyright 1995 Canadian Economics Association. 
Kalwij, A. and Vermeulen, F. (2008). Health and labour force participation of older people in europe: What do objective health indicators add to the analysis? Health Economics, 17(5):619-638.

Larsson, D., Hemmingsson, T., Allebeck, P., and Lundberg, I. (2002). Self-rated health and mortality among young men: what is the relation and how may it be explained? Scandinavian Journal of Public Health, 30(4):259-266.

Lee, L.-F. (1982). Health and wage: A simultaneous equation model with multiple discrete indicators. International Economic Review, 23(1):199-221.

Lindeboom, M. and van Doorslaer, E. (2004). Cut-point shift and index shift in self-reported health. Journal of Health Economics, 23(4):1083-1099.

Martinez-Granado, M. (2005). Testing labour supply and hours constraints. Labour Economics, 12(3):321-343.

Merz, J. (2002). Time and economic well-being - a panel analysis of desired versus actual working hours. Review of Income and Wealth, 48(3):317-346.

Pelkowski, J. M. and Berger, M. C. (2004). The impact of health on employment, wages, and hours worked over the life cycle. The Quarterly Review of Economics and Finance, 44(1):102 - 121.

Riphahn, R. (1999). Income and employment effects of health shocks a test case for the german welfare state. Journal of Population Economics, 12(3):363-389.

Stewart, M. B. and Swaffield, J. K. (1997). Constraints on the desired hours of work of british men. Economic Journal, 107(441):520-35.

Verbeek, M. and Nijman, T. (1992). Testing for selectivity bias in panel data models. International Economic Review, 33(3):681-703.

Wagner, G., Frick, J., and Schupp, J. (2007). The german socio-economic panel study (soep) : Scope, evolution and enhancements. Schmollers Jahrbuch : Journal of Applied Social Science Studies / Zeitschrift für Wirtschafts- und Sozialwissenschaften, 127(1):139-169.

Wannamethe, L. and Shaper, A. (1991). Self-assessment of health status and mortality in middle-aged british men. International Journal of Epidemiology, 20(2):239-245. 
Wolf, E. (2000). Loosening hours constraints on the supply of labor: what if germans had a dutch labor market? Technical report, ZEW - Zentrum für Europäische Wirtschaftsforschung / Center for European Economic Research.

Wooldridge, J. M. (2004). Econometric Analysis of Cross Section and Panel Data. Massachusetts Institute of Technology, Massachusetts. 


\section{Tables}

Table 1: Health and disability status by year and employment status

\begin{tabular}{|c|c|c|c|c|c|c|c|c|}
\hline \multirow[t]{3}{*}{ Year } & \multicolumn{4}{|c|}{ Non-employed } & \multicolumn{4}{|c|}{ Employed } \\
\hline & \multicolumn{2}{|c|}{ West } & \multicolumn{2}{|c|}{ East } & \multicolumn{2}{|c|}{ West } & \multicolumn{2}{|c|}{ East } \\
\hline & $\mathrm{PH}^{a}$ & Disab. $^{b}$ & $\mathrm{PH}^{a}$ & Disab. ${ }^{b}$ & $\mathrm{PH}^{a}$ & Disab. ${ }^{b}$ & $\mathrm{PH}^{a}$ & Disab. $^{b}$ \\
\hline 1997 & 39.9 & 13.0 & 43.0 & 7.6 & 39.9 & 7.8 & 43.8 & 5.9 \\
\hline 1998 & 43.5 & 13.9 & 49.3 & 10.0 & 40.9 & 9.4 & 44.1 & 5.1 \\
\hline 1999 & 42.6 & 16.8 & 57.2 & 11.1 & 39.8 & 8.7 & 43.9 & 5.1 \\
\hline 2000 & 51.2 & 19.7 & 51.3 & 14.6 & 40.3 & 8.3 & 44.2 & 4.3 \\
\hline 2001 & 48.9 & 23.4 & 55.6 & 12.9 & 38.5 & 6.7 & 39.4 & 4.5 \\
\hline 2002 & 46.1 & 18.8 & 55.8 & 15.3 & 40.5 & 7.7 & 42.1 & 4.1 \\
\hline 2003 & 52.0 & 18.6 & 48.8 & 12.1 & 39.9 & 9.0 & 43.9 & 3.5 \\
\hline 2004 & 56.2 & 20.3 & 49.1 & 10.3 & 39.7 & 9.5 & 41.5 & 4.9 \\
\hline 2005 & 55.7 & 23.2 & 53.9 & 16.4 & 45.0 & 10.1 & 43.5 & 4.4 \\
\hline 2006 & 62.9 & 24.2 & 48.5 & 18.3 & 43.3 & 9.1 & 38.9 & 4.5 \\
\hline
\end{tabular}

${ }^{a}$ PH: poor health; ${ }^{b}$ Disab.: disability

Source: Authors' calculations based on SOEP 1997 - 2006

Table 2: Observations by year and samples

\begin{tabular}{lcccccc}
\hline Year & \multicolumn{3}{c}{ FE \& RE Sample } & \multicolumn{3}{c}{ GMM Sample } \\
& All & West & East & All & West & East \\
\hline 1997 & 2148 & 1546 & 602 & 0 & 0 & 0 \\
1998 & 2071 & 1503 & 568 & 0 & 0 & 0 \\
1999 & 2331 & 1721 & 610 & 1495 & 1105 & 390 \\
2000 & 2270 & 1664 & 606 & 1491 & 1099 & 392 \\
2001 & 3418 & 2628 & 790 & 1638 & 1227 & 411 \\
2002 & 3203 & 2466 & 737 & 1589 & 1192 & 397 \\
2003 & 3027 & 2342 & 685 & 2348 & 1824 & 524 \\
2004 & 2876 & 2203 & 673 & 2224 & 1733 & 491 \\
2005 & 2646 & 2047 & 599 & 2089 & 1647 & 442 \\
2006 & 2463 & 1892 & 571 & 2004 & 1565 & 439 \\
\hline Total & 27767 & 21196 & 6571 & 15460 & 11930 & 3530 \\
\hline Source: Authors' calculations based on SOEP 1996-2007
\end{tabular}


Table 3: Descriptive statistics: Regression samples

\begin{tabular}{|c|c|c|c|c|c|c|}
\hline & \multicolumn{3}{|c|}{ FE/RE Sample } & \multicolumn{3}{|c|}{ GMM Sample } \\
\hline & All & West & East & All & West & East \\
\hline Des. - act. hours & -4.01 & -3.74 & -4.87 & -3.86 & -3.63 & -4.65 \\
\hline Actual hours & 42.9 & 42.4 & 44.5 & 42.7 & 42.3 & 44.3 \\
\hline Health: & & & & & & \\
\hline SAH - Very good & 0.10 & 0.11 & 0.07 & 0.08 & 0.09 & 0.06 \\
\hline SAH - Good & 0.51 & 0.50 & 0.51 & 0.50 & 0.50 & 0.51 \\
\hline SAH - Satisfactory & 0.31 & 0.30 & 0.34 & 0.32 & 0.31 & 0.35 \\
\hline SAH - Not so good & 0.08 & 0.08 & 0.07 & 0.09 & 0.09 & 0.07 \\
\hline $\mathrm{SAH}-\mathrm{Bad}$ & 0.01 & 0.01 & 0.01 & 0.01 & 0.01 & 0.01 \\
\hline "Poor health" & 0.40 & 0.39 & 0.42 & 0.42 & 0.41 & 0.43 \\
\hline Disability & 0.06 & 0.07 & 0.05 & 0.06 & 0.07 & 0.05 \\
\hline East German & 0.24 & 0 & 1 & 0.23 & 0 & 1 \\
\hline Age & 40.1 & 39.9 & 40.8 & 41.3 & 41.0 & 42.2 \\
\hline Low edu. & 0.30 & 0.36 & 0.12 & 0.29 & 0.35 & 0.09 \\
\hline Middle edu. & 0.41 & 0.36 & 0.60 & 0.42 & 0.37 & 0.61 \\
\hline Higher edu. & 0.28 & 0.28 & 0.29 & 0.28 & 0.28 & 0.30 \\
\hline Married & 0.70 & 0.71 & 0.68 & 0.74 & 0.75 & 0.73 \\
\hline Kids 0-4 & 0.19 & 0.20 & 0.13 & 0.18 & 0.20 & 0.13 \\
\hline Kids 5-10 & 0.29 & 0.33 & 0.17 & 0.31 & 0.35 & 0.17 \\
\hline Kids 11-18 & 0.39 & 0.39 & 0.40 & 0.41 & 0.42 & 0.40 \\
\hline Foreigner & 0.16 & 0.21 & 0.01 & 0.16 & 0.21 & 0.01 \\
\hline Selection 1 & 0.09 & 0.08 & 0.12 & 0.05 & 0.04 & 0.06 \\
\hline Selection 2 & 0.20 & 0.18 & 0.28 & 0.11 & 0.11 & 0.14 \\
\hline$N$ & 27767 & 21196 & 6571 & 15460 & 11930 & 3530 \\
\hline
\end{tabular}


Table 4: Difference of desired and actual hours, sample: West

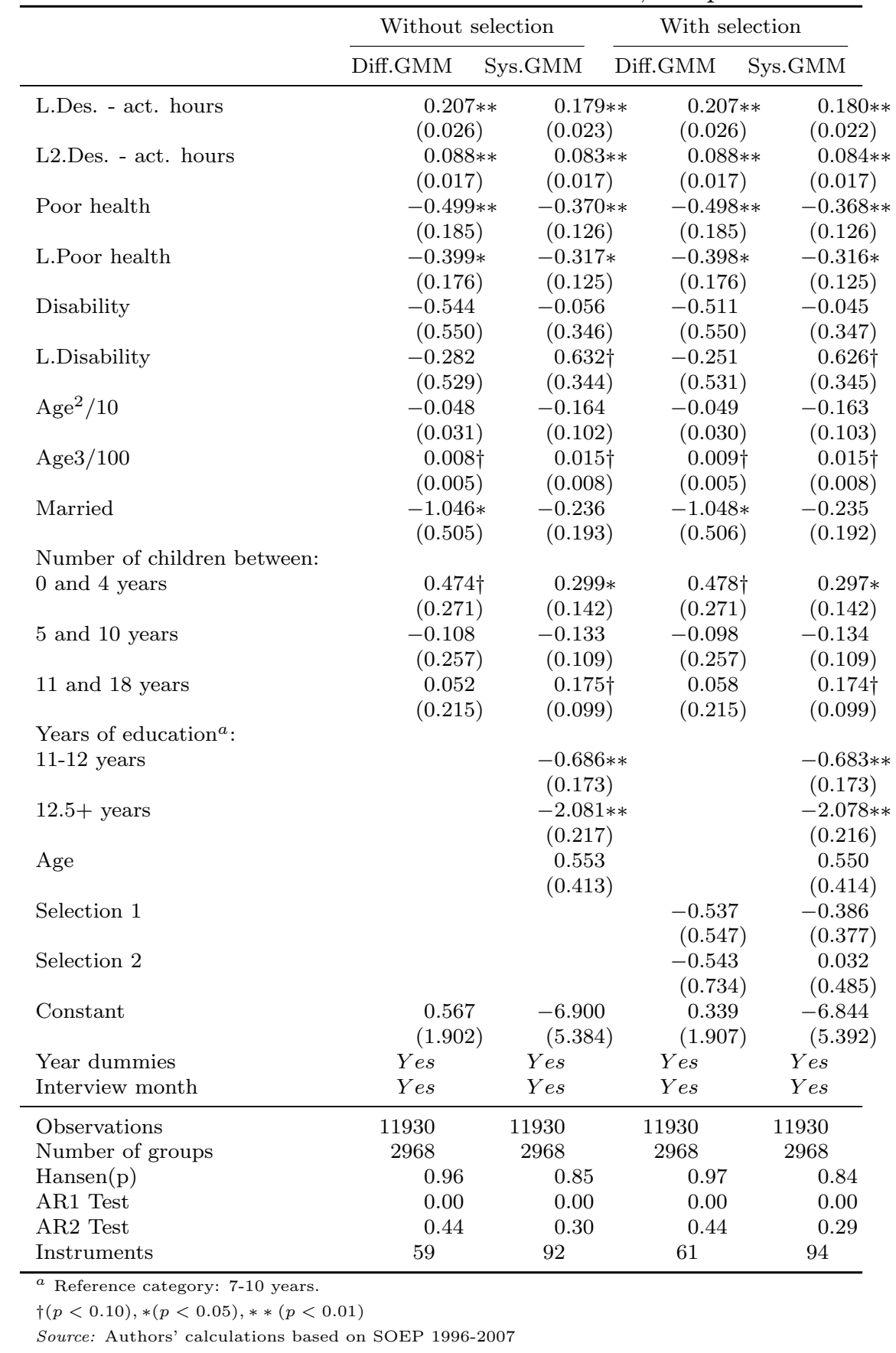


Table 5: Difference of desired and actual hours, sample: East

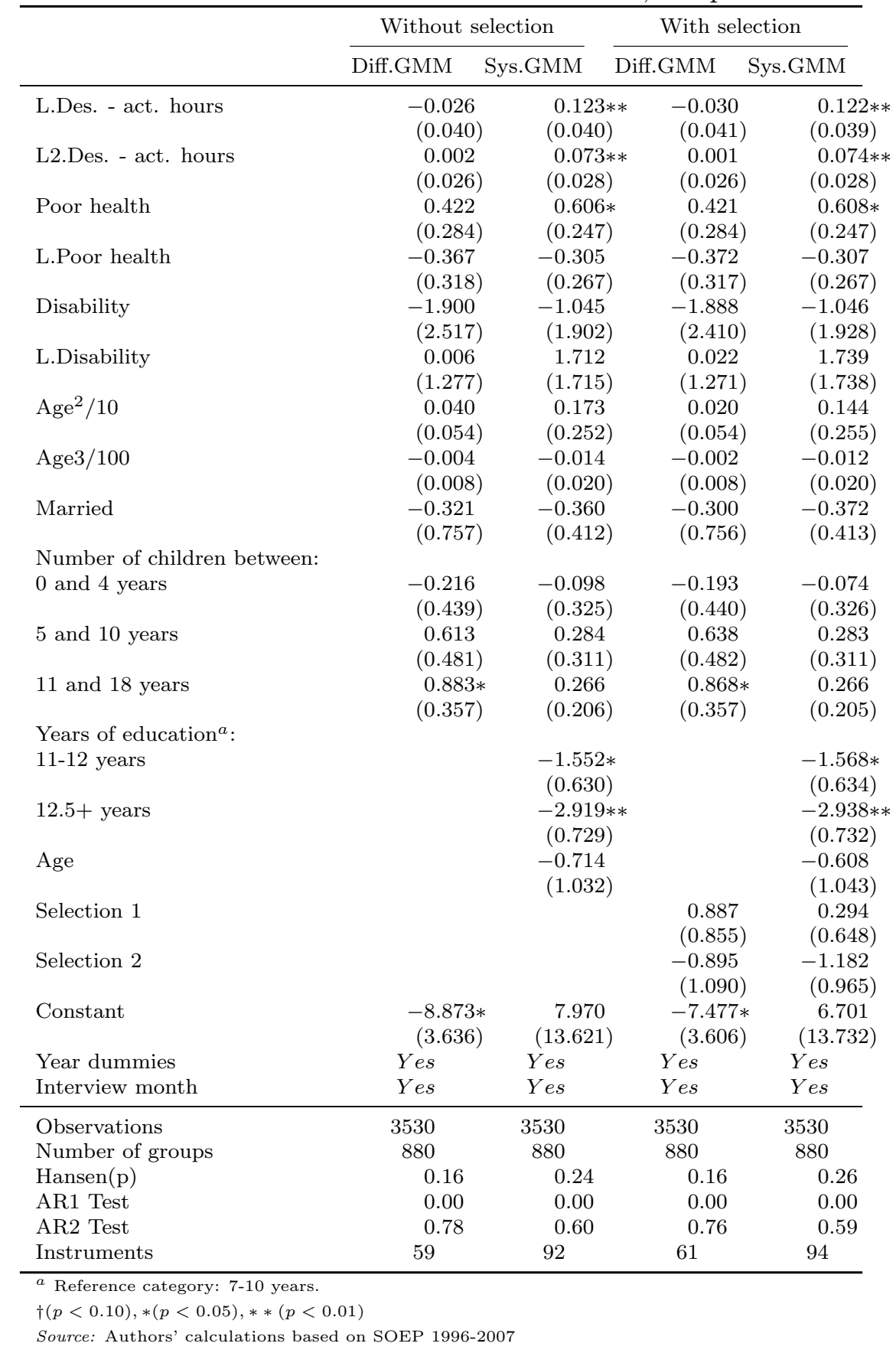


Table 6: Difference of desired and actual hours, sample: west and east

\begin{tabular}{|c|c|c|c|c|c|c|c|c|}
\hline & \multicolumn{4}{|c|}{ West } & \multicolumn{4}{|c|}{ East } \\
\hline & \multicolumn{2}{|c|}{ Without selection } & \multicolumn{2}{|c|}{ With selection } & \multicolumn{2}{|c|}{ Without selection } & \multicolumn{2}{|c|}{ With selection } \\
\hline & $\mathrm{RE}$ & $\mathrm{FE}$ & $\mathrm{RE}$ & $\mathrm{FE}$ & $\mathrm{RE}$ & $\mathrm{FE}$ & $\mathrm{RE}$ & $\mathrm{FE}$ \\
\hline Poor health & $\begin{array}{r}-0.415 * * \\
(0.106)\end{array}$ & $\begin{array}{r}-0.418 * * \\
(0.117)\end{array}$ & $\begin{array}{r}-0.414 * * \\
(0.106)\end{array}$ & $\begin{array}{r}-0.418 * * \\
(0.117)\end{array}$ & $\begin{array}{r}0.089 \\
(0.215)\end{array}$ & $\begin{array}{r}0.148 \\
(0.241)\end{array}$ & $\begin{array}{r}0.063 \\
(0.215)\end{array}$ & $\begin{array}{r}0.138 \\
(0.241)\end{array}$ \\
\hline Disability & $\begin{array}{l}-0.059 \\
(0.258)\end{array}$ & $\begin{array}{l}-0.264 \\
(0.330)\end{array}$ & $\begin{array}{l}-0.075 \\
(0.258)\end{array}$ & $\begin{array}{l}-0.263 \\
(0.330)\end{array}$ & $\begin{array}{r}0.259 \\
(0.662)\end{array}$ & $\begin{array}{l}-0.073 \\
(0.994)\end{array}$ & $\begin{array}{r}0.123 \\
(0.661)\end{array}$ & $\begin{array}{l}-0.151 \\
(0.994)\end{array}$ \\
\hline Years of education & & & & & & & & \\
\hline $11-12$ years & $\begin{array}{r}-0.943 * * \\
(0.220)\end{array}$ & & $\begin{array}{r}-0.937 * * \\
(0.220)\end{array}$ & & $\begin{array}{l}-0.520 \\
(0.533)\end{array}$ & & $\begin{array}{l}-0.364 \\
(0.531)\end{array}$ & \\
\hline $12.5+$ years & $\begin{array}{r}-2.245 * * \\
(0.232)\end{array}$ & & $\begin{array}{r}-2.238 * * \\
(0.232)\end{array}$ & & $\begin{array}{r}-2.038 * * \\
(0.577)\end{array}$ & & $\begin{array}{r}-1.808 * * \\
(0.576)\end{array}$ & \\
\hline Age & $\begin{array}{l}-0.433 \\
(0.297)\end{array}$ & $\begin{array}{r}-0.723 \dagger \\
(0.396)\end{array}$ & $\begin{array}{l}-0.474 \\
(0.298)\end{array}$ & $\begin{array}{r}-0.736 \dagger \\
(0.398)\end{array}$ & $\begin{array}{l}-0.936 \\
(0.580)\end{array}$ & $\begin{array}{l}-0.770 \\
(0.785)\end{array}$ & $\begin{array}{r}-0.980 \dagger \\
(0.581)\end{array}$ & $\begin{array}{l}-0.796 \\
(0.787)\end{array}$ \\
\hline $\mathrm{Age}^{2} / 10$ & $\begin{array}{r}0.054 \\
(0.076)\end{array}$ & $\begin{array}{r}0.153 \\
(0.100)\end{array}$ & $\begin{array}{r}0.065 \\
(0.077)\end{array}$ & $\begin{array}{r}0.156 \\
(0.101)\end{array}$ & $\begin{array}{r}0.199 \\
(0.149)\end{array}$ & $\begin{array}{r}0.214 \\
(0.198)\end{array}$ & $\begin{array}{r}0.214 \\
(0.149)\end{array}$ & $\begin{array}{r}0.223 \\
(0.199)\end{array}$ \\
\hline Age $3 / 100$ & $\begin{array}{l}-0.001 \\
(0.006)\end{array}$ & $\begin{array}{l}-0.009 \\
(0.008)\end{array}$ & $\begin{array}{l}-0.002 \\
(0.006)\end{array}$ & $\begin{array}{l}-0.010 \\
(0.008)\end{array}$ & $\begin{array}{l}-0.013 \\
(0.012)\end{array}$ & $\begin{array}{l}-0.015 \\
(0.016)\end{array}$ & $\begin{array}{l}-0.015 \\
(0.012)\end{array}$ & $\begin{array}{l}-0.016 \\
(0.016)\end{array}$ \\
\hline Married & $\begin{array}{r}-0.498 * * \\
(0.177)\end{array}$ & $\begin{array}{r}-0.516 * \\
(0.237)\end{array}$ & $\begin{array}{r}-0.495 * * \\
(0.177)\end{array}$ & $\begin{array}{r}-0.525 * \\
(0.237)\end{array}$ & $\begin{array}{r}-1.401 * * \\
(0.370)\end{array}$ & $\begin{array}{r}-1.142 * \\
(0.551)\end{array}$ & $\begin{array}{r}-1.327 * * \\
(0.369)\end{array}$ & $\begin{array}{r}-1.152 * \\
(0.551)\end{array}$ \\
\hline Number of children & & & & & & & & \\
\hline 0 and 4 years & $\begin{array}{r}0.163 \\
(0.120)\end{array}$ & $\begin{array}{r}0.276 \dagger \\
(0.142)\end{array}$ & $\begin{array}{r}0.162 \\
(0.120)\end{array}$ & $\begin{array}{r}0.279 * \\
(0.142)\end{array}$ & $\begin{array}{l}-0.223 \\
(0.297)\end{array}$ & $\begin{array}{l}-0.382 \\
(0.357)\end{array}$ & $\begin{array}{l}-0.234 \\
(0.297)\end{array}$ & $\begin{array}{l}-0.372 \\
(0.357)\end{array}$ \\
\hline 5 and 10 years & $\begin{array}{r}0.042 \\
(0.101)\end{array}$ & $\begin{array}{r}0.107 \\
(0.130)\end{array}$ & $\begin{array}{r}0.041 \\
(0.101)\end{array}$ & $\begin{array}{r}0.109 \\
(0.130)\end{array}$ & $\begin{array}{r}0.351 \\
(0.268)\end{array}$ & $\begin{array}{r}0.301 \\
(0.331)\end{array}$ & $\begin{array}{r}0.341 \\
(0.267)\end{array}$ & $\begin{array}{r}0.310 \\
(0.331)\end{array}$ \\
\hline 11 and 18 years & $\begin{array}{r}0.255 * * \\
(0.091)\end{array}$ & $\begin{array}{r}0.179 \\
(0.118)\end{array}$ & $\begin{array}{r}0.254 * * \\
(0.091)\end{array}$ & $\begin{array}{r}0.181 \\
(0.118)\end{array}$ & $\begin{array}{r}0.209 \\
(0.192)\end{array}$ & $\begin{array}{r}0.144 \\
(0.240)\end{array}$ & $\begin{array}{r}0.199 \\
(0.192)\end{array}$ & $\begin{array}{r}0.135 \\
(0.240)\end{array}$ \\
\hline Selection 1 & & & $\begin{array}{l}-0.248 \\
(0.213)\end{array}$ & $\begin{array}{r}-0.493 * \\
(0.237)\end{array}$ & & & $\begin{array}{r}1.110 * * \\
(0.345)\end{array}$ & $\begin{array}{r}0.875 * \\
(0.393)\end{array}$ \\
\hline Selection 2 & & & $\begin{array}{r}0.566 \\
(0.357)\end{array}$ & $\begin{array}{l}-0.005 \\
(0.422)\end{array}$ & & & $\begin{array}{r}1.662 * * \\
(0.572)\end{array}$ & $\begin{array}{r}0.687 \\
(0.692)\end{array}$ \\
\hline Constant & $6.428 \dagger$ & 6.842 & $6.920 \dagger$ & 7.040 & 9.682 & 1.202 & 9.712 & 1.394 \\
\hline & $(3.691)$ & $(5.029)$ & $(3.699)$ & $(5.048)$ & $(7.194)$ & $(9.955)$ & $(7.194)$ & $(9.985)$ \\
\hline Year dummies & Yes & No & Yes & No & Yes & No & Yes & No \\
\hline Interview month & Yes & Yes & Yes & Yes & Yes & Yes & Yes & Yes \\
\hline Observations & 21196 & 21196 & 21196 & 21196 & 6571 & 6571 & 6571 & 6571 \\
\hline Number of groups & 4499 & 4499 & 4499 & 4499 & 1458 & 1458 & 1458 & 1458 \\
\hline Random vs. pooled: & 0.00 & & 0.00 & & 0.00 & & 0.00 & \\
\hline FE vs. RE: Hausman & & 0.00 & & 0.00 & & 0.19 & & 0.08 \\
\hline
\end{tabular}

$\dagger(p<0.10), *(p<0.05), * *(p<0.01)$

Source: Authors' calculations based on SOEP 1996-2007 
Table 7: RE and FE estimates on static and GMM samples: west

\begin{tabular}{|c|c|c|c|c|c|c|c|c|}
\hline \multirow[b]{2}{*}{ Sample: } & \multicolumn{4}{|c|}{ Random effects } & \multicolumn{4}{|c|}{ Fixed effects } \\
\hline & $\mathrm{RE} / \mathrm{FE}-1$ & GMM & RE/FE-2 & GMM & $\mathrm{RE} / \mathrm{FE}-1$ & GMM & $\mathrm{RE} / \mathrm{FE}-2$ & GMM \\
\hline Poor health & $\begin{array}{c}-0.414 * * \\
(0.106)\end{array}$ & $\begin{array}{c}*-0.400 * * \\
(0.124)\end{array}$ & $\begin{array}{c}-0.320 * * \\
(0.115)\end{array}$ & $\begin{array}{c}-0.375 * * \\
(0.125)\end{array}$ & $\begin{array}{c}-0.418 * * \\
(0.117)\end{array}$ & $\begin{array}{c}-0.299 * \\
(0.140)\end{array}$ & $\begin{array}{r}-0.235 \dagger \\
(0.128)\end{array}$ & $\begin{array}{c}-0.317 * \\
(0.140)\end{array}$ \\
\hline L.Poor health & & & $\begin{array}{r}-0.198 \dagger \\
(0.116)\end{array}$ & $\begin{array}{c}-0.297 * \\
(0.126)\end{array}$ & & & $\begin{array}{r}-0.196 \\
(0.129)\end{array}$ & $\begin{array}{r}-0.243 \dagger \\
(0.142)\end{array}$ \\
\hline Disability & $\begin{array}{r}-0.075 \\
(0.258)\end{array}$ & $\begin{array}{c}0.137 \\
(0.301)\end{array}$ & $\begin{array}{c}-0.431 \\
(0.319)\end{array}$ & $\begin{array}{c}-0.148 \\
(0.351)\end{array}$ & $\begin{array}{r}-0.263 \\
(0.330)\end{array}$ & $\begin{array}{c}0.013 \\
(0.416)\end{array}$ & $\begin{array}{r}-0.295 \\
(0.371)\end{array}$ & $\begin{array}{c}-0.018 \\
(0.421)\end{array}$ \\
\hline L.Disability & & & $\begin{array}{l}0.955 * * \\
(0.330)\end{array}$ & $\begin{array}{r}0.689 \dagger \\
(0.358)\end{array}$ & & & $\begin{array}{r}0.816 * \\
(0.381)\end{array}$ & $\begin{array}{c}0.293 \\
(0.424)\end{array}$ \\
\hline Years of education ${ }^{a}$ : & & & & & & & & \\
\hline $11-12$ years & $\begin{array}{c}-0.937 * * \\
(0.220)\end{array}$ & $\begin{array}{c}*-0.940 * * \\
(0.241)\end{array}$ & $\begin{array}{c}-0.858 * * \\
(0.226)\end{array}$ & $\begin{array}{c}-0.930 * * \\
(0.241)\end{array}$ & & & & \\
\hline $12.5+$ years & $\begin{array}{c}-2.238 * * \\
(0.232)\end{array}$ & $\begin{array}{c}-2.720 * * \\
(0.258)\end{array}$ & $\begin{array}{c}-2.665 * * \\
(0.241)\end{array}$ & $\begin{array}{c}-2.729 * * \\
(0.258)\end{array}$ & & & & \\
\hline Age & $\begin{array}{c}-0.474 \\
(0.298)\end{array}$ & $\begin{array}{c}0.221 \\
(0.467)\end{array}$ & $\begin{array}{c}-0.410 \\
(0.376)\end{array}$ & $\begin{array}{c}0.229 \\
(0.467)\end{array}$ & $\begin{array}{r}-0.736 \dagger \\
(0.398)\end{array}$ & $\begin{array}{r}-0.397 \\
(0.685)\end{array}$ & $\begin{array}{r}-0.954 \dagger \\
(0.526)\end{array}$ & $\begin{array}{r}-0.375 \\
(0.686)\end{array}$ \\
\hline $\mathrm{Age}^{2} / 10$ & $\begin{array}{c}0.065 \\
(0.077)\end{array}$ & $\begin{array}{c}-0.101 \\
(0.116)\end{array}$ & $\begin{array}{c}0.052 \\
(0.095)\end{array}$ & $\begin{array}{c}-0.102 \\
(0.116)\end{array}$ & $\begin{array}{c}0.156 \\
(0.101)\end{array}$ & $\begin{array}{c}0.081 \\
(0.168)\end{array}$ & $\begin{array}{r}0.228 \dagger \\
(0.131)\end{array}$ & $\begin{array}{c}0.076 \\
(0.168)\end{array}$ \\
\hline Age3/100 & $\begin{array}{r}-0.002 \\
(0.006)\end{array}$ & $\begin{array}{c}0.011 \\
(0.009)\end{array}$ & $\begin{array}{c}-0.001 \\
(0.008)\end{array}$ & $\begin{array}{c}0.011 \\
(0.009)\end{array}$ & $\begin{array}{r}-0.010 \\
(0.008)\end{array}$ & $\begin{array}{c}-0.004 \\
(0.013)\end{array}$ & $\begin{array}{r}-0.016 \\
(0.011)\end{array}$ & $\begin{array}{c}-0.003 \\
(0.013)\end{array}$ \\
\hline Married & $\begin{array}{c}-0.495 * * \\
(0.177)\end{array}$ & $\begin{array}{c}-0.499 * \\
(0.214)\end{array}$ & $\begin{array}{r}-0.381 * \\
(0.192)\end{array}$ & $\begin{array}{r}-0.493 * \\
(0.214)\end{array}$ & $\begin{array}{r}-0.525 * \\
(0.237)\end{array}$ & $\begin{array}{c}-0.933 * * \\
(0.318)\end{array}$ & $\begin{array}{r}-0.653 * \\
(0.273)\end{array}$ & $\begin{array}{c}-0.936 * * \\
(0.318)\end{array}$ \\
\hline Number of children between: & & & & & & & & \\
\hline 0 and 4 years & $\begin{array}{c}0.162 \\
(0.120)\end{array}$ & $\begin{array}{r}0.306 * \\
(0.150)\end{array}$ & $\begin{array}{c}0.149 \\
(0.133)\end{array}$ & $\begin{array}{c}0.305 * \\
(0.149)\end{array}$ & $\begin{array}{c}0.279 * \\
(0.142)\end{array}$ & $\begin{array}{c}0.422 * \\
(0.188)\end{array}$ & $\begin{array}{r}0.306 \dagger \\
(0.163)\end{array}$ & $\begin{array}{c}0.426 * \\
(0.188)\end{array}$ \\
\hline 5 and 10 years & $\begin{array}{c}0.041 \\
(0.101)\end{array}$ & $\begin{array}{c}-0.033 \\
(0.123)\end{array}$ & $\begin{array}{c}0.031 \\
(0.110)\end{array}$ & $\begin{array}{c}-0.032 \\
(0.122)\end{array}$ & $\begin{array}{c}0.109 \\
(0.130)\end{array}$ & $\begin{array}{c}0.121 \\
(0.175)\end{array}$ & $\begin{array}{c}0.134 \\
(0.151)\end{array}$ & $\begin{array}{c}0.128 \\
(0.175)\end{array}$ \\
\hline 11 and 18 years & $\begin{array}{l}0.254 * * \\
(0.091)\end{array}$ & $\begin{array}{r}0.195 \dagger \\
(0.110)\end{array}$ & $\begin{array}{r}0.192 \dagger \\
(0.099)\end{array}$ & $\begin{array}{r}0.201 \dagger \\
(0.110)\end{array}$ & $\begin{array}{c}0.181 \\
(0.118)\end{array}$ & $\begin{array}{c}0.154 \\
(0.159)\end{array}$ & $\begin{array}{c}0.114 \\
(0.136)\end{array}$ & $\begin{array}{c}0.161 \\
(0.159)\end{array}$ \\
\hline Selection 1 & $\begin{array}{c}-0.248 \\
(0.213)\end{array}$ & $\begin{array}{r}-0.602 \dagger \\
(0.308)\end{array}$ & $\begin{array}{r}-0.523 * \\
(0.262)\end{array}$ & $\begin{array}{r}-0.590 \dagger \\
(0.308)\end{array}$ & $\begin{array}{c}-0.493 * \\
(0.237)\end{array}$ & $\begin{array}{c}-0.899 * \\
(0.361)\end{array}$ & $\begin{array}{r}-0.344 \\
(0.297)\end{array}$ & $\begin{array}{c}-0.898 * \\
(0.361)\end{array}$ \\
\hline Selection 2 & $\begin{array}{c}0.566 \\
(0.357)\end{array}$ & $\begin{array}{c}0.241 \\
(0.495)\end{array}$ & $\begin{array}{c}0.133 \\
(0.427)\end{array}$ & $\begin{array}{c}0.237 \\
(0.494)\end{array}$ & $\begin{array}{r}-0.005 \\
(0.422)\end{array}$ & $\begin{array}{r}-0.010 \\
(0.582)\end{array}$ & $\begin{array}{c}0.251 \\
(0.512)\end{array}$ & $\begin{array}{r}-0.013 \\
(0.582)\end{array}$ \\
\hline Constant & $\begin{array}{r}6.920 \dagger \\
(3.699)\end{array}$ & $\begin{array}{r}-2.250 \\
(6.059)\end{array}$ & $\begin{array}{c}5.641 \\
(4.788)\end{array}$ & $\begin{array}{r}-2.378 \\
(6.055)\end{array}$ & $\begin{array}{c}7.040 \\
(5.048)\end{array}$ & $\begin{array}{c}2.201 \\
(9.026)\end{array}$ & $\begin{array}{c}8.426 \\
(6.815)\end{array}$ & $\begin{array}{c}1.904 \\
(9.028)\end{array}$ \\
\hline Year dummies & Yes & Yes & Yes & Yes & No & No & No & No \\
\hline Interview month & Yes & Yes & Yes & Yes & Yes & Yes & Yes & Yes \\
\hline Observations & 21196 & 11930 & 15800 & 11930 & 21196 & 1930 & 15800 & 11930 \\
\hline Number of groups & 4499 & 2968 & 3595 & 2968 & 4499 & 2968 & 3595 & 2968 \\
\hline $\begin{array}{l}\text { Random vs. pooled: LM Test } \\
\text { FE vs. RE: Hausman Test }\end{array}$ & 0.00 & 0.00 & 0.00 & 0.00 & 0.00 & 0.00 & 0.00 & 0.00 \\
\hline
\end{tabular}

FE and RE refer to the sample for static and dynamic panel models. GMM refers to the sample necessary for the dynamic GMM estimators.

${ }^{a}$ Reference category: 7-10 years.

$\dagger(p<0.10), *(p<0.05), * *(p<0.01)$

Source: Authors' calculations based on SOEP 1996-2007 
Table 8: RE and FE estimates on static and GMM samples: east

\begin{tabular}{|c|c|c|c|c|c|c|c|c|}
\hline \multirow[b]{2}{*}{ Sample: } & \multicolumn{4}{|c|}{ Random effects } & \multicolumn{4}{|c|}{ Fixed effects } \\
\hline & $\mathrm{RE} / \mathrm{FE}-1$ & GMM & $\mathrm{RE} / \mathrm{FE}-2$ & GMM & $\mathrm{RE} / \mathrm{FE}-1$ & GMM & $\mathrm{RE} / \mathrm{FE}-2$ & GMM \\
\hline Poor health & $\begin{array}{c}0.063 \\
(0.215)\end{array}$ & $\begin{array}{r}0.467 \dagger \\
(0.253)\end{array}$ & $\begin{array}{c}0.275 \\
(0.238)\end{array}$ & $\begin{array}{c}0.500 * \\
(0.255)\end{array}$ & $\begin{array}{c}0.138 \\
(0.241)\end{array}$ & $\begin{array}{l}0.605 * \\
(0.285)\end{array}$ & $\begin{array}{c}0.408 \\
(0.264)\end{array}$ & $\begin{array}{r}0.584 * \\
(0.287)\end{array}$ \\
\hline L.Poor health & & & $\begin{array}{r}-0.223 \\
(0.238)\end{array}$ & $\begin{array}{r}-0.339 \\
(0.255)\end{array}$ & & & $\begin{array}{r}-0.138 \\
(0.263)\end{array}$ & $\begin{array}{r}-0.251 \\
(0.287)\end{array}$ \\
\hline Disability & $\begin{array}{c}0.123 \\
(0.661)\end{array}$ & $\begin{array}{c}0.645 \\
(0.846)\end{array}$ & $\begin{array}{c}0.643 \\
(1.002)\end{array}$ & $\begin{array}{c}0.304 \\
(1.127)\end{array}$ & $\begin{array}{r}-0.151 \\
(0.994)\end{array}$ & $\begin{array}{c}0.326 \\
(1.428)\end{array}$ & $\begin{array}{c}0.360 \\
(1.213)\end{array}$ & $\begin{array}{c}0.226 \\
(1.449)\end{array}$ \\
\hline L.Disability & & & $\begin{array}{c}0.467 \\
(1.024)\end{array}$ & $\begin{array}{c}0.640 \\
(1.129)\end{array}$ & & & $\begin{array}{c}0.105 \\
(1.221)\end{array}$ & $\begin{array}{c}0.469 \\
(1.400)\end{array}$ \\
\hline $\begin{array}{l}\text { Years of education }{ }^{a}: \\
11-12 \text { years }\end{array}$ & $\begin{array}{c}-0.364 \\
(0.531)\end{array}$ & $\begin{array}{r}-1.073 \\
(0.730)\end{array}$ & $\begin{array}{r}-0.387 \\
(0.651)\end{array}$ & $\begin{array}{l}-1.093 \\
(0.730)\end{array}$ & & & & \\
\hline $12.5+$ years & $\begin{array}{c}-1.808 * * \\
(0.576)\end{array}$ & $\begin{array}{c}* 2.934 * * \\
(0.769)\end{array}$ & $\begin{array}{r}-1.706 * \\
(0.695)\end{array}$ & $\begin{array}{cc}* & -2.973 * * \\
& (0.769)\end{array}$ & & & & \\
\hline Age & $\begin{array}{r}-0.980 \dagger \\
(0.581)\end{array}$ & $\begin{array}{c}-1.193 \\
(0.979)\end{array}$ & $\begin{array}{c}-1.118 \\
(0.770)\end{array}$ & $\begin{array}{c}-1.213 \\
(0.979)\end{array}$ & $\begin{array}{r}-0.796 \\
(0.787)\end{array}$ & $\begin{array}{c}-1.164 \\
(1.404)\end{array}$ & $\begin{array}{r}-1.507 \\
(1.055)\end{array}$ & $\begin{array}{r}-1.187 \\
(1.405)\end{array}$ \\
\hline $\mathrm{Age}^{2} / 10$ & $\begin{array}{c}0.214 \\
(0.149)\end{array}$ & $\begin{array}{c}0.277 \\
(0.240)\end{array}$ & $\begin{array}{c}0.236 \\
(0.193)\end{array}$ & $\begin{array}{c}0.283 \\
(0.240)\end{array}$ & $\begin{array}{c}0.223 \\
(0.199)\end{array}$ & $\begin{array}{c}0.294 \\
(0.341)\end{array}$ & $\begin{array}{c}0.372 \\
(0.261)\end{array}$ & $\begin{array}{c}0.301 \\
(0.341)\end{array}$ \\
\hline Age3/100 & $\begin{array}{c}-0.015 \\
(0.012)\end{array}$ & $\begin{array}{c}-0.021 \\
(0.019)\end{array}$ & $\begin{array}{r}-0.016 \\
(0.016)\end{array}$ & $\begin{array}{r}-0.022 \\
(0.019)\end{array}$ & $\begin{array}{r}-0.016 \\
(0.016)\end{array}$ & $\begin{array}{l}-0.021 \\
(0.027)\end{array}$ & $\begin{array}{l}-0.026 \\
(0.021)\end{array}$ & $\begin{array}{r}-0.022 \\
(0.027)\end{array}$ \\
\hline Married & $\begin{array}{c}-1.327 * * \\
(0.369)\end{array}$ & $\begin{array}{c}-0.681 \\
(0.451)\end{array}$ & $\begin{array}{r}-0.768 \dagger \\
(0.417)\end{array}$ & $\begin{array}{r}-0.670 \\
(0.451)\end{array}$ & $\begin{array}{r}-1.152 * \\
(0.551)\end{array}$ & $\begin{array}{c}-0.789 \\
(0.704)\end{array}$ & $\begin{array}{c}-0.785 \\
(0.630)\end{array}$ & $\begin{array}{r}-0.788 \\
(0.705)\end{array}$ \\
\hline Number of children between: & & & & & & & & \\
\hline 0 and 4 years & $\begin{array}{r}-0.234 \\
(0.297)\end{array}$ & $\begin{array}{c}0.115 \\
(0.361)\end{array}$ & $\begin{array}{r}-0.341 \\
(0.333)\end{array}$ & $\begin{array}{c}0.116 \\
(0.361)\end{array}$ & $\begin{array}{r}-0.372 \\
(0.357)\end{array}$ & $\begin{array}{c}0.260 \\
(0.445)\end{array}$ & $\begin{array}{c}-0.304 \\
(0.397)\end{array}$ & $\begin{array}{c}0.266 \\
(0.445)\end{array}$ \\
\hline 5 and 10 years & $\begin{array}{c}0.341 \\
(0.267)\end{array}$ & $\begin{array}{c}0.592 \dagger \\
(0.338)\end{array}$ & $\begin{array}{c}0.438 \\
(0.306)\end{array}$ & $\begin{array}{r}0.589 \dagger \\
(0.338)\end{array}$ & $\begin{array}{c}0.310 \\
(0.331)\end{array}$ & $\begin{array}{c}0.912 * \\
(0.435)\end{array}$ & $\begin{array}{r}0.684 \dagger \\
(0.380)\end{array}$ & $\begin{array}{r}0.922 * \\
(0.435)\end{array}$ \\
\hline 11 and 18 years & $\begin{array}{c}0.199 \\
(0.192)\end{array}$ & $\begin{array}{c}0.299 \\
(0.234)\end{array}$ & $\begin{array}{c}0.095 \\
(0.216)\end{array}$ & $\begin{array}{c}0.305 \\
(0.234)\end{array}$ & $\begin{array}{c}0.135 \\
(0.240)\end{array}$ & $\begin{array}{c}0.460 \\
(0.298)\end{array}$ & $\begin{array}{c}0.233 \\
(0.269)\end{array}$ & $\begin{array}{c}0.471 \\
(0.298)\end{array}$ \\
\hline Selection 1 & $\begin{array}{l}1.110 * * \\
(0.345)\end{array}$ & * $\begin{array}{r}0.908 \dagger \\
(0.528)\end{array}$ & $\begin{array}{c}0.619 \\
(0.446)\end{array}$ & $\begin{array}{r}0.933 \dagger \\
(0.529)\end{array}$ & $\begin{array}{c}0.875 * \\
(0.393)\end{array}$ & $\begin{array}{c}1.222 * \\
(0.602)\end{array}$ & $\begin{array}{r}0.847 \dagger \\
(0.510)\end{array}$ & $\begin{array}{r}1.247 * \\
(0.603)\end{array}$ \\
\hline Selection 2 & $\begin{array}{l}1.662 * * \\
(0.572)\end{array}$ & $* \begin{array}{c}0.298 \\
(0.816)\end{array}$ & $\begin{array}{c}0.378 \\
(0.718)\end{array}$ & $\begin{array}{c}0.310 \\
(0.816)\end{array}$ & $\begin{array}{c}0.687 \\
(0.692)\end{array}$ & $\begin{array}{c}0.211 \\
(0.966)\end{array}$ & $\begin{array}{c}1.166 \\
(0.850)\end{array}$ & $\begin{array}{c}0.218 \\
(0.966)\end{array}$ \\
\hline Constant & $\begin{array}{c}9.712 \\
(7.194)\end{array}$ & $\begin{array}{c}12.967 \\
(12.837)\end{array}$ & $\begin{array}{l}11.973 \\
(9.831)\end{array}$ & $\begin{array}{c}13.234 \\
(12.837)\end{array}$ & $\begin{array}{c}1.394 \\
(9.985)\end{array}$ & $\begin{array}{c}7.468 \\
(18.658)\end{array}$ & $\begin{array}{c}11.734 \\
(13.704)\end{array}$ & $\begin{array}{c}7.724 \\
(18.671)\end{array}$ \\
\hline Year dummies & Yes & Yes & Yes & Yes & No & No & No & No \\
\hline Interview month & Yes & Yes & Yes & Yes & Yes & Yes & Yes & Yes \\
\hline Observations & 6571 & 3530 & 4727 & 3530 & 6571 & 3530 & 4727 & 3530 \\
\hline Number of groups & 1458 & 880 & 1094 & 880 & 1458 & 880 & 1094 & 880 \\
\hline $\begin{array}{l}\text { Random vs. pooled: LM Test } \\
\text { FE vs. RE: Hausman Test }\end{array}$ & 0.00 & 0.00 & 0.00 & 0.00 & 0.08 & 0.50 & 0.00 & 0.60 \\
\hline
\end{tabular}

